\title{
PENGARUH BUDAYA ORGANISASI, KOMPETENSI SUMBER DAYA MANUSIA, DAN PERENCANAAN KARIR TERHADAP KINERJA KARYAWAN PERBANKAN SYARIAH DI KOTA MEDAN
}

\author{
Anggia Sari Lubis ${ }^{1)}$ \\ Arief Hadian 2) \\ Universitas Muslim Nusantara Al-Wasliyah \\ Jl. Garu 2A No. 93 Medan Sumatera Utara \\ anggiasarilubis@gmail.com
}

\begin{abstract}
Abstrak
Tujuan dari penelitian ini adalah untuk mengukur seberapa besar pengaruh budaya organisasi, kompetensi sumber daya manusia dan perencanaan karir karyawan terhadap kinerja karyawan Perbankan Syariah di Kota Medan. Penelitian ini menggunakan pendekatan survey, adapun sifat dari penelitian ini adalah penjelasan dan jenis penelitian adalah deskriptif kuantitatif. Sampel penelitian ini adalah 90 orang karyawan Perbankan Syariah di Kota Medan.Metode pengumpulan data dalam penelitian ini menggunakan kuesioner. Kuesioner dalam penelitian ini dengan memberikan atau menyebar daftar pertanyaan kepada responden, dari hasil penelitian yang telah memenuhi uji validitas, uji reliabilitas dan uji asumsi klasik diolah sehingga menghasilkan persamaan regresi sebagai berikut, $Y=0.740 x 1+-0.125 X 2+0.325 X 3+\boldsymbol{e}$. Hasil model regresi linier berganda mendapatkan bahwa ketiga variable yaitu budaya organisasi, kompetensi sumber daya manusia dan perencanaan karir memiliki pengaruh positif terhadap kinerja karyawan perbankan syariah di Kota Medan. Nilai koefisien determinasi $\left(R^{2}\right)$ yang diperoleh sebesar 0,593. Hal ini berarti 59,3\% kinerja karyawan dapat dijelaskan oleh variabel budaya organisasi, kompetensi sumber daya manusia dan perencanaan karir. Dan Berdasarkan hasil uji secara parsial (Uji t) diperoleh bahwa variabel yang paling dominan dalam mempengaruhi kinerja karyawan adalah budaya orgnisasi dengan nilai t hitung 0,8513 lebih besar dibanding nilai $t$ hitung variabel kompetensi sumber daya manusia dan perencanaan karir.
\end{abstract}

Kata Kunci : Pengaruh Budaya Organisasi, Kompetensi Sumberdaya Manusia, Perencanaan Karir dan Kinerja Karyawan Perbankan Syariah

\begin{abstract}
The purpose of this study is to measure how big the influence of organizational culture, human resource competence and career planning of employees on the performance of employees of Sharia Banking in Medan City. This research use survey approach, while the nature of this research is explanation and research type is descriptive quantitative. The sample of this research is 90 employees of Banking Syariah in Medan City. Data collection method in this study using questionnaire. Questionnaires in this study by giving or distributing a list of questions to respondents, from the results of research that has met the validity test, reliability test and classical assumption test processed so as to produce the following regression equation, $Y=0.740 X 1+-0.125 X 2+0.325 X 3+e$. The result of multiple linear regression model found that the three variables of organizational culture, human resource competence and career planning have a positive influence on the performance of sharia banking employees in Medan City. The value of determination coefficient $\left(R^{2}\right)$ obtained is 0,593. This means that 59.3\% of employee performance can be
\end{abstract}


explained by organizational culture variables, human resource competencies and career planning. And Based on the results of partial test (Test t) obtained that the most dominant variable in affecting employee performance is orgnisasi culture with a value of $0.8513 t$ count greater than the value $t$ arithmetic variable competence of human resources and career planning.

Keywords: Influence of Organizational Culture, Human Resource Competence, Career Planning and Employee Performance of Sharia Banking

\section{PENDAHULUAN}

\subsection{Latar Belakang}

Perbankan syariah merupakan salah satu lembaga keuangan yang beroperasi berdasarkan prinsip islam yang memiliki peran penting dalam mendorong pertumbuhan perekonomian suatu Negara, salah satunya di Indonesia. Disamping itu, bank syariah juga merupakan lembaga keuangan yang memberikan jasa yang paling lengkap. Peran sebagai penghimpun dana dilakukan bank dengan melayani pihak yang ingin menabungkan uangnya di bank. Usaha yang dilakukan disamping menghimpun dana dari masyarakat luas dalam bentuk simpanan, juga menyalurkan atau memberikan pinjaman dalam bentuk kredit. Dengan peran dan fungsi yang dimiliki , pihak perbankan syariah di tanah air harus mengatur strategi agar dapat mempertahankan diri dari berbagai ancaman yang berasal dari lingkungan eksternal dan kelemahankelemahan yang dimiliki dari lingkungan internal.

Salah satu tugas perbankan syariah saat ini yang dianggap penting ialah mengubah pola pikir masyarakat mengenai prinsip yang dianut perbankan syariah memang dilaksanakan dengan penuh komitmen tidak hanya sekedar perubahan istilah, dari istilah umum yang sering digunakan bank konvensional, kepada istilah islami yang digunakan bank syariah. Selain itu pola pikir yang berkembang pada masyarakat saat ini ialah biaya yang dikenakan bank syariah lebih mahal dibanding bank konvensional yang mengakibatkan calon nasabah enggan untuk bertransaksi di bank syariah.

Untuk dapat tetap eksis dan bertahan dari ketatnya persaingan, dan krisis ekonomi global saat ini, sektor perbankan dituntut untuk memiliki karyawan dengan kinerja tinggi yang mendukung pencapaian visi, misi, dan tujuan yang telah dirumuskan, serta menghadapi berbagai tantangan yang muncul. Karena kinerja karyawan merupakan faktor utama yang menentukan keberhasilan suatu perusahaan dan juga merupakan aset perusahaan yang paling bernilai tinggi jika dibandingkan dengan sumber daya lain. Konteks pemberdayaan sumber daya manusia agar menghasilkan karyawan yang profesional dengan kinerja tinggi, diperlukan adanya acuan baku bagiperusahaan dan nilai inti yang dianut bersama oleh semua anggota perusahaan yaitu budaya organisasi yang secara otomatis menuntut perusahaan untuk meningkatkan komitmen kerja karyawan bagi organisasi.

Hubungan antara budaya organisasi dengan sukses atau gagalnya kinerja suatu perusahaan diyakini oleh para ilmuwan perilaku organisasi dan manajemen serta sejumlah peneliti memiliki hubungan yang sangat erat. Budaya organisasi diyakini merupakan faktor penentu 
utama terhadap peningkatan kinerja individu dan kesuksesan kinerja perusahaan. Budaya di dalam sebuah organisasi bukan sekedar kebiasaan atau ritual yang seringkali dilakukan oleh perusahaan. Lebih dari itu, kebiasaan atau ritual tersebut tentunya dilakukan untuk suatu tujuan, yaitu mencapai visi, misi, dan tujuan perusahaan. Budaya organisasi menjadi wahana bagi pendiri atau pemimpin perusahaan dalam mengkomunikasikan harapanharapannya kepada seluruh karyawan. Peran dan keberadaan budaya organisasi di dalam sebuah perusahaan tidak dapat disepelekan. Penerapan budaya organisasi yang sesuai bagi perusahaan akan membawa dampak positif bagi karyawan dan kesuksesan bagi perusahaan. Budaya organisasi dapat sangat stabil sepanjang waktu, tetapi juga tidak pernah statis.

Budaya organisasi perlu disesuaikan dengan perkembangan yang ada di masyarakat, namun tetap disesuaikan dengan kebutuhan organisasi. Hal ini perlu dilakukan agar dengan tugas pekerjaan setiap karyawan. Kompetensi sumber daya manusia terutama diperlukan untuk menjawab tuntutan perusahaan, dimana adanya perubahan yang sangat cepat, perkembangan masalah yang sangat kompleks dan dinamis, serta ketidakpastian masa depan dalam tatanan kehidupan masyarakat. Setiap perusahaan harus mengidektifikasi dan mengembangkan kompetensi sumber daya manusia kerah kinerja karyawan.

Persoalan yang terjadi adalah sumber daya manusia yang ada di dalam organisasi tidak dapat mendukung jabatan atau pekerjaan yang diberikan kepada pegawai.
Karena adanya ketidaksesuaian kompetensi yang dimiliki pegawai terhadap perusahaan dapat bertahan dalam menghadapi persaingan usaha yang semakin ketat sekarang ini. Peningkatan kinerja bagi setiap karyawan harus diikuti dengan persoalan yang terjadi adalah sumber daya manusia yang ada di dalam organisasi tidak dapat mendukung jabatan atau pekerjaan yang diberikan kepada pegawai. Karena adanya ketidaksesuaian kompetensi yang dimiliki pegawai terhadap jabatan yang sedang diduduki. Ketidak sesuaian ini akan memberikan dampak bagi penurunan kinerja pegawai yang pada akhirnya berpengaruh kepada kepemilikan kompentensi tidak dapat tercapainya tujuan yang telah ditetapkan organisasi. Seiring dengan meningkatnya peran dan fungsi perbankan di Indonesia ke depan, maka kebutuhan akan karyawan yang memiliki kompetensi mutlak diperlukan.

Pentingnya kompetensi sumber daya manusia bagi sektor perbankan menuntut perusahaan untuk menghilangkan ketidaksesuaian kompetensi dengan jabatan. Alternatif solusi yang dapat ditempuh adalah dengan membuat perencanaan karir bagi para pegawai. Fokus utama perencanaan karir haruslah pada kesesuaian tujuan pribadi pegawai dan kesempatankesempatan yang secara realistis tersedia. Perencanaan karir sepatutnya tidak hanya terkonsentrasi pada kesempatan-kesempatan promosi. Perencanaan karir perlu pula terfokus pada pencapaian keberhasilan psikologis yang tidak harus selalu memerlukan promosi.

Kenyataan yang terjadi ialah perencanaan karir bagi para karyawan 
cenderung tidak linier dengan jabatan yang sedang dijalani, latar belakang pendidikan, keahlian dan jenis pelatihan yang diikuti. Seorang pegawai mendapatkan promosi kepada jabatan yang lebih tinggi tetapi tidak linier dengan jabatan sebelumnya. Dampak yang mungkin timbul dari kejadian ini adalah karyawan yang dipromosikan pada jabatan baru tidak memiliki kompetensi yang sesuai dengan kebutuhan kompetensi yang dibutuhkan jabatan dan pada akhirnya akan berdampak pada penurunan kinerja karyawan .Berdasarkan uraian sebelumnya, penulis tertarik untuk melakukan penelitian dengan judul

$$
\text { "Pengaruh Budaya }
$$

Organisasi, Kompetensi Sumber Daya Manusia, dan Perencanaan Karir terhadap Kinerja Karyawan Perbankan Syariah Di Kota Medan ".

\subsection{Tujuan Penelitian}

Berdasarkan uraian latar belakang dan perumusan masalah, maka tujuan penelitian ini adalah untuk " Mengetahui dan menganalisis budaya organisasi, kompetensi sumber daya manusia dan perencanaan karir berpengaruh secara simultan dan parsial terhadap kinerja karyawan perbankan syariah di kota medan."

\section{METODE}

Populasi adalah keseluruhan subjek penelitian (Lubis, 2012). Populasi yang digunakan dalam penelitian ini adalah seluruh perusahaan perbankan syariah yang berkedudukan di kota medan. Sampel adalah sebagian atau wakil populasi yang diteliti (Lubis, 2012). Metode pengambilan sampel yang digunakan adalah metode purposive sampling.
Purposive sampling adalah metode pengambilan sampel berdasarkan suatu kriteria tertentu, kriteria yang digunakan dapat berdasarkan judgement atau kuota tertentu (Erlina, 2011).

Adapun kriteria-kriteria yang digunakan dalam penelitian ini adalah sebagai berikut:

1. Perusahaan perbankan syariah yang berdiri dan beroperasi minimal 10 tahun.

2. Perusahaan tersebut telah memiliki panduan budaya organisasi, memiliki program peningkatan kompetensi dan perencanaan karir bagi karyawan.

Dari hasil kriteria di atas, perusahaan yang memenuhi kriteria untuk dijadikan sampel adalah sebanyak 3 perusahaan, dimana untuk setiap perusahaan akan diambil 30 orang untuk dijadikan responden, dengan masa penelitian 1 tahun

TABEL 1

\section{Daftar Perbankan Syariah Yang} Sudah Berdiri 10 Tahun

\begin{tabular}{|c|c|c|}
\hline No. & Nama Bank & $\begin{array}{l}\text { Tahun } \\
\text { Berdiri }\end{array}$ \\
\hline 1. & $\begin{array}{l}\text { Bank Muamalat } \\
\text { Indonesia }\end{array}$ & 1991 \\
\hline 2. & $\begin{array}{ll}\text { Bank } & \text { Syariah } \\
\text { Mandiri } & \end{array}$ & 1999 \\
\hline 3. & $\begin{array}{l}\text { Bank Syariah } \\
\text { Mega Indonesia }\end{array}$ & 2004 \\
\hline
\end{tabular}

Sumber: Hasil Penelitian, 2016 (Data Diolah)

Metode pengumpulan data yang digunakan dalam penelitian ini adalah:

1. Wawancara (interview), yang dilakukan kepada Kepala divisi sumber daya manusia pada bank muammalat, bank syariah mandiri, dan bank syariah mega yang berkedudukan di kota medan atau 
pihak-pihak lain yang ditunjuk oleh organisasi untuk memberikan informasi dan keterangan yang dibutuhkan dalam penelitian ini.

2. Daftar pertanyaan (questionairre), yang diberikan kepada karyawan kantor pusat bank muammalat indonesia, bank syariah mandiri, dan bank syariah mega indonesia yang berkedudukan di kota medan yang menjadi responden dalam penelitian ini.

3. Studi dokumentasi, dilakukan dengan mengumpulkan dan mempelajari dokumen-dokumen yang diperoleh dari bank muammalat indonesia, bank syariah mandiri dan bank syariah mega indonesia yang berupa sejarah singkat berdirinya organisasi, struktur organisasi, jumlah karyawan, booklet budaya organisasi, kamus kompetensi sumber daya manusia, serta detail dan jenis pengembangan sumber daya manusia.

\section{HASIL DAN PEMBAHASAN}

Berdasarkan dari hasil analisis dengan program SPSS maka diperoleh hasil regresi antara budaya organisasi, kompetensi sumber daya manusia, dan perencanaan karier terhadap kinerja karyawan adalah sebagai berikut:

\section{Tabel 2 Hasil Uji Regresi}

\begin{tabular}{|c|c|c|c|c|c|c|}
\hline \multirow[t]{2}{*}{ Model } & & \multicolumn{2}{|c|}{ Unsiandardicet Coefficiants } & \multirow{2}{*}{ 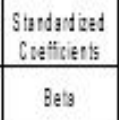 } & \multirow[t]{2}{*}{$\mathrm{t}$} & \multirow{2}{*}{ Sig } \\
\hline & & $B$ & Std. Error & & & \\
\hline 1 & (Consinef) & 6.412 & 2.098 & & 3.056 & \\
\hline & $\mathrm{X}_{1}$ & .740 & .087 & .699 & 8.513 & .00 \\
\hline & $\mathrm{X} 2$ & .125 & .110 & .089 & 1.141 & .01 \\
\hline & $\mathrm{X} 3$ & .325 & .164 & .167 & 1.983 & .01 \\
\hline
\end{tabular}

a. Dependent Variable: $Y$

\section{Sumber: Hasil Penelitian (2016) (Data Diolah)}

Dari hasil regresi maka dapat dibuat persamaan regresiberganda sebagai berikut: $\mathrm{Y}=\mathbf{0 . 7 4 0 X 1}+\mathbf{+ 0 . 1 2 5} \mathrm{X} 2+$ $0.325 \mathrm{X3}+\mathrm{e}$

Persamaan regresi tersebut mempunyai arti sebagai berikut:

1. Koefisien regresi budaya organisasi (b1) bernilai positif sebesar 0,740, hal ini menunjukkan budaya organisasi berpengaruh positif dan signifikan terhadap kinerja karyawan. Sehingga dengan adanya peningkatan program implementasi budaya organisasi pada masing-masingkaryawan, akan meningkatkan kinerja karyawan perbankan syariah di Kota Medan. Peningkatan implementasi budaya organisasi dalam satu satuan unit, akan diikuti dengan peningkatan kinerja karyawan sebesar $74.0 \%$.

2. Koefisien regresi kompetensi sumber daya manusai (b2) bernilai positif sebesar 0,125 , hal ini menunjukkan kompetensi sumber daya manusia berpengaruh positif dan signifikan terhadap kinerja karyawan. Sehingga dengan adanya peningkatan kompetensi Sumberdayamanusiaakan meningkatkan kinerja karyawan perbankan syariah di Kota Medan. Peningkatan kompetensi sumber daya manusia dalam satu satuan unit, akan diikuti dengan peningkatan kinerja karyawan sebesar $12,5 \%$.

3. Koefisien regresi perencanaan karir (b3) bernilai positif sebesar 0,325 , hal ini menunjukkan adanya program perencanaan karir bagi karyawan berpengaruh positif dan signifikan terhadap kinerja karyawan. Sehingga dengan 
adanya program perencanaan karir bagi karyawan akan meningkatkan kinerja karyawan. Adanya program perencanaan karir karyawan dalam satu satuan unit, akan diikuti dengan peningkatan kinerja karyawan sebesar 32,5\%.

Nilai koefisien determinasi $\left(\mathrm{R}^{2}\right)$ dipergunakan untuk mengetahui pengaruh variable bebas budaya organisasi (X1), kompetensi sumber daya manusia (X2), dan perencanaan karir (X3) terhadap kinerja karyawan (Y).

Tabel 3. Hasil Uji Koefisien Determinasi

\begin{tabular}{c|c|c|c|c|}
\hline Model & $R$ & R Square & $\begin{array}{c}\text { Adjusted } \\
\text { R Square }\end{array}$ & $\begin{array}{c}\text { Std. Error } \\
\text { of the } \\
\text { Estimate }\end{array}$ \\
\hline 1 & $.770^{9}$ & .593 & .577 & 198.856 \\
\hline
\end{tabular}
a. Predictors: (Constant), X3, X2, X1
b. Dependent Variable: $Y$

Sumber: Hasil Penelitian (2016) (Data Diolah)

Berdasarkan table, diperoleh nilai Adjusted R Square sebesar 0,577 dan mendekati angka 1, dengan demikian budaya organisasi, kompetensi sumber daya manusia, dan perencanaan karir mampu menjelaskan hampir semua variasi dari variable kinerja karyawan, sehingga model regresi yang digunakan fit atau baik. Berdasarkan nilai R Square dapat diartikan pula budaya organisasi, kompetensi sumber daya manusia, dan perencanaan karir mampu mempengaruhi kinerja karyawan yaitu sebesar 59,3\%.

Hasil pengujian hipotesis secara serempak dapat dilihat pada table berikut ini:

Tabel 4. Hasil Uji Serempak (Uji F) ANOVA $^{b}$

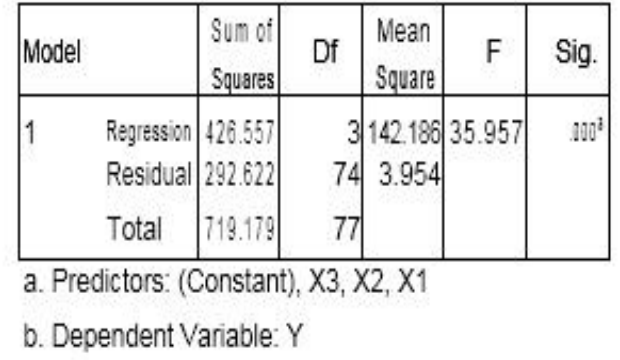

Sumber: Hasil Penelitian (2016) (Data Diolah)

Berdasarkan tabel 4 diperoleh bahwa nilai Fhitung (35.957) lebih besar dibandingkan dengan nilai Ftabel (3.15) dan sig. $\alpha\left(.000^{\mathrm{a}}\right)$ lebih kecil dari alpha $5 \%(0,05)$. Hal ini mengindikasikan bahwa hasil penelitian menolak $\mathrm{HO}$ dan menerima Ha. Dengan demikian secara serempak budaya organisasi, kompetensi sumber daya manusia, dan perencanaan karir berpengaruh sangat signifikan (high significant) terhdap kinerja karyawan perbankan syariah di Kota Medan . Ini memberi arti bahwa budaya organisasi, kompetensi sumber daya manusia dan perencanaan karir sangat menentukan dalam meningkatkan kinerja karyawan. Hasil pengujian hipotesis secara parsial dapat dilihat pada table berikut ini:

\section{Tabel 5. Hasil Uji Parsial (Uji}

t)

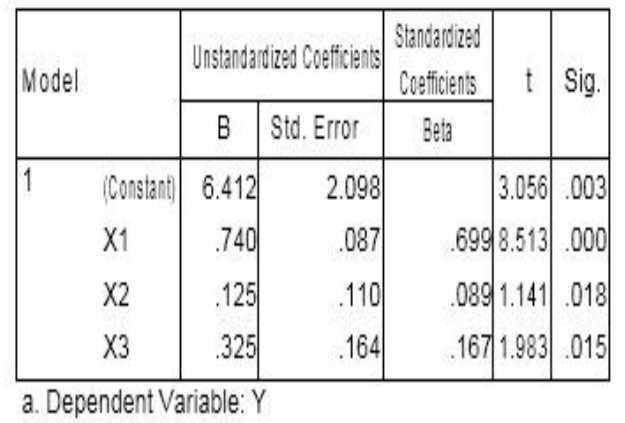

Sumber: Hasil Penelitian (2016) (Data Diolah)

Berdasarkan table diperoleh hasil sebagai berikut: 
1. Nilai $t$ hitung untuk variable budaya organisasi 8.513 lebih besar dibandingkan nilai $\mathrm{t}$ table (2.000), atau nilai sig.t untuk variable budaya organisasi $(0,000)$ lebih kecil dari alpha $(0,025)$. Ini berarti budaya organisasi berpengaruh dominan terhadap kinerja karyawan perbankan syariah di kota medan. Budaya Organisasi memiliki pengaruh yang lebih dominan daripada kompetensi sumber daya manusia, dan perencanaan karir dalam mempengaruhi kinerja karyawan, karena budaya organisasi bagi para karyawan merupakan sesuatu yang sakral, dengan pengimplementasian budaya organisasi kepada setiap karuawan, nilai inti organisasi dipegang secara intensif dan dianut bersama secara meluas. Perbankan syariah yang menjadi objek dalam penelitian ini yaitu Bank Syariah mandiri dengan budaya organisasi "ETHIC" Bank Muamalat dengan budaya organisasi "PROMISE" dan Bank Mega Syariah dengan budaya organisasi yaitu "Integrity, Sinergy and Excellence”yang diterapkan kepada setiap karyawan dan dianut dengan baik oleh setiap karyawan akan meningkatkan kinerja individu dan pada akhirnya akan meningkatkan kinerja organisasi dalam menjawab tantangan eksternal yang semakin berat dalam era globalisasi dan teknologi yang semakin berkembang pesat. Karyawan akan bekerja dengan pelayanan cepat, tanggap, dan amanah yang menjaga keramahan, responsive, dan konsisten dalam pelayanan, seperti halnya konsisten dalam membudayakan cara berpakaian dengan tampilan yang Islami, keramahan dalam tutur katanya dan responsive dalam layanan sesuai dengan syariat Islam.

2. Nilai thitung untuk variable kompetensi sumber daya manusia yaitu (1.141) lebih besar dibandingkan dengan nilaittabel (2.000), atau nilai sig.t untuk variable kompetensi sumber daya manusia (0.018) lebih kecil dari alpha $(0,025)$. Ini berarti kompetensi sumber daya manusia berpengaruh terhadap kinerja karyawan perbankan syariah di kota medan. Ini berarti kompetensi sumber daya manusia yang dimiliki setiap karyawan berpengaruh terhadap kinerja karyawan. Perbankan Syariah di Kota Medan harus berupaya untuk meningkatkan kompetensi sumber daya manusia agar setiap karyawan dapat bekerja secara lebih efektif dan efisien. Perbankan Syariah Medan harus memperhatikan kesesuaian antara kompetensi yang dimiliki masingmasing karyawan dengan jabatan yang sedang diduduki dan tuntutan pekerjaan dalam jabatan tersebut. Adanya hubungan kausal antara kompetensi sumber daya manusia dengan kinerja yaitu jika seorang karyawan memiliki kompetensi yang tinggi, maka akan mempunyai kinerja yang tinggi pula.

3. Nilai thitung untuk variable perencanaan karir (1.983) lebih besar dibandingkan dengan nilai ttabel (2.000), atau nilai sig.t untuk variable perencanaan karir $(0.015)$ lebih kecil dari alpha $(0,025)$. Ini berarti perencanaan karir berpengaruh terhadap kinerja karyawan perbankan syariah di kota medan. Dengan adanya 


\begin{abstract}
perencanaan karir, seorang
karyawan dituntut untuk mengevaluasi kemampuan dan minat karyawan sendiri, mempertimbangkan kesempatan karir alternatif, menyusun sasaran karir dan merencanakan aktivitasaktivitas perencanaan karir secara praktis. Hal tersebut menjadikan karyawan berupaya untuk meningkatkan kinerja melalui peningkatan pengetahuan yang dibutuhkan oleh jabatan, pemahaman akan pekerjaan secara lebih mendalam, peningkatan kemampuan dalam melaksanakan tugas atau pekerjaan dan peningkatan minat dalam bekerja.
\end{abstract}

\section{KESIMPULAN}

Dari hasil analisis data dan pembahasan yang telah dilakukan dalam penelitian ini serta sesuai dengan tujuan penelitian, maka dapat disimpulkan sebagai berikut:

1. Hasil dari uji regresi menunjukkan bahwa ketiga variabel independen, yaitu budaya organisasi, kompetensi sumber daya manusia dan perencanaan karir memiliki nilai positif. Artinya, semakin baik perusahaan dalam mengimplementasikan budaya organisasi dikalangan para karyawan, semakin baik kompetensi sumber daya manusia dan semakin baik penerapan perencanaan karir pada masingmasing karyawan maka kinerja karyawan perbankan syariah di kota medan akan semakin tinggi.

2. Variabel budaya organisasi berpengaruh paling besar, yaitu sebesar 8,513 terhadap kinerja karyawan perbankan syariah di kota medan, diikuti variabel perencanaan karir sebesar 1,983, dan kompetensi sumber daya manusia yang memiliki pengaruh paling kecil sebesar 1,141.

3. Hasil uji F, secara simultan ketiga variabel independen yaitu budaya organisasi, kompetensi sumber daya manusia dan perencanaan karir berpengaruh signifikan terhadap variabel kinerja karyawan dengan nilai signifikansi sebesar 0,000.

4. Uji koefisien determinasi sebesar 0,593 menunjukkan bahwa variabel kinerja karyawan perbankan di kota medan dapat dijelaskan 59,3\% oleh variabel budaya organisasi, kompetensi sumber daya manusia, dan perencanaan karir. Sedangkan sisanya $\quad 40,7 \%$ dipengaruhi variabel lain di luar penelitian ini.

\section{DAFTAR PUSTAKA}

Bacal, Robert. 2001. Performance Management. Jakarta: Gramedia Pustaka Utama.

Becker, Brian E, Mark A Huselid, Dave Ulrich .2009. The HR Score Card. Jakarta: Penerbit Erlangga

Cooper, Donald R, Pamela Schlinder . 2006. Metode Riset Bisnis . Jakarta : Media Global Edukasi

Dessler, Gary, Agus Dharma. 2005. Manajemen Personalia. Jakarta : Penerbit Erlangga

Erlina . 2008. Metodologi Penelitian$$
\text { Untuk Akuntansi dan }
$$

Manajemen. Medan : USU Press

Ghozali, Imam . 2009. Aplikasi Analisis Multivariate Dengan Program SPSS.

Semarang : Badan Penerbit Universitas Diponegoro

Gomes, Faustino Cardoso. 2005. Manajemen Sumber Daya 
Manusia. Yogyakarta: Andi Offset.

Grensing-Pophal, Lin. 2008. Human Resource Book. Jakarta : Prenada.

Hariandja, Marihot Tua Effendi. 2002.

Manajemen Sumber

$$
\text { Daya }
$$

Manusia. Cetakan pertama. Jakarta: Gramedia Widia Sarana.

Hasibuan, Malayu SP . 2007. Manajemen Sumber Daya Manusia. Jakarta : Bumi Aksara. Ivancevich, John, Robert Konopaske, Michael T Matteson. 2006. Perilaku Organisasi.Jakarta : Penerbit Erlangga

Kotter,JP, J.L Heskett. 2000. Corporate Culture And Performance. New York : Free Press

Kountur, Ronny. 2007. Metode Penelitian Untuk Penelitian Skripsi dan Tesis. Jakarta : Penerbit PPM

Mangkunegara. 200. Sumber Daya Manusia Perusahaan. Bandung: Penerbit Rosdakarya.

Martoyo, Susilo. 2007. Manajemen Sumber Daya Manusia. Jakarta: BPFE

Mathis, Robert, John H Jackson. 2006. Manajemen Sumber Daya Manusia. Salemba Empat: Jakarta

Moeheriono . 2009. Pengukuran Kinerja Berbasis Kompetensi . Bogor: Ghalia Indonesia

Noe, Raymond A. 2002 . Employee Training \& Development. New York : Mc Graw Hill

Prasetyo, Miftahuljannah. 2007. Metode Penelitian Kuantitatif. Jakarta Rajawali Press
Ranupandojo, Hedjrachman dan Suad Husnan. 2002. Manajemen Personalia. Yogyakarta: Edisi 4 Penerbit BPFE

Rivai, Veithzal . 2004. Manajemen Sumber Daya Manusia Untuk Perusahaan. Jakarta: Raja Grafindo.

Robbins, Stephen P . 2003. Perilaku Organisasi. Jakarta : Penerbit Indeks

Sekaran, Uma. 2006. Research Methods For Bussiness. Jakarta : Salemba Empat

Saydam, $\quad$ Gouzali. 1996. Manajemen Sumber Daya Manusia. Jakarta : PT. Toko Gunung Agung.

Sofyandi, Herman . 2008. Manajemen Sumber Daya Manusia . Yogyakarta : Graha Ilmu

Sugiyono. 2003. Metode Penelitian Bisnis. Cetakan Ketujuh. Bandung: Alfabeta

Sumarsono, Sony . 2004. Metode Riset SDM. Yogyakarta : Graha Ilmu

Sutrisno, Edy . 2010. Manajemen Sumber Daya Manusia. Jakarta : Prenada Media Group

Umar, Husein. 2008. Desain Penelitian MSDM dan Perilaku Karyawan. Jakarta : PT. Raja Grafindo Persada. 